\title{
How 'here' and 'now' in Russian and English establish joint attention in TV news broadcasts
}

\begin{abstract}
This article presents a thorough investigation of the five Russian deictic words that correspond to the English meanings 'here' and 'now': zdes', tut, sejčas, teper' and vot. We analyze data from the Russian National Corpus and data from Russian TV news broadcasts. On the basis of the corpus data, we propose a radial category network consisting of nine subcategories, which encompass all five words, and show that although the deictic words have overlapping distributions, they all have distinct "radial category profiles" in the sense that they display different centers of gravity in the network. We advance the "Minimal Adaptation Hypothesis", according to which language makes adaptations that are as small as possible, when applied to a new setting, such as the one created by TV.
\end{abstract}

Аннотация: В статье представлено тщательное исследование пяти дейктических слов русского языка, соответсвующих английским местоимениям 'here' и 'now': здесь, тут, сейчас, теперь и вот. Мы проанализировали данные Национального корпуса русского языка, а также данные русских телевизионных выпусков новостей. На основе данных корпуса мы предлагаем радиальную сеть значений, состоящую из девяти подкатегорий и описывающую все пять дейктических слов. Мы показываем, что, хотя исследуемые дейктические единицы пересекаются в их распределении, каждая из них имеет свой «профиль радиальной категории», иными словами, свой центр тяжести в рамках предложенной радиальной сети значений. Мы также выдвигаем «гипотезу минимальной адаптации», согласно которой приспособление языка к новым условиям функционирования, таким как условия телевидения, оказывается по возможности минимальным.

Keywords: Deixis, radial category profiling, blended joint attention, corpus data, language in the media

\section{Overview and contribution}

What happens to language when it adapts to a new setting? In this article, we explore this question by investigating the use of Russian spatial and temporal deictic words in TV news. TV creates a new setting for language to adapt to since the communication situation is different - what is 'here' and 'now' for a news anchor is not necessarily 'here' and 'now' for the viewers. Therefore, the question arises as to how deictic words are used in TV broadcasts. Russian provides a perfect testing ground for this question since it has five deictic words that correspond approximately to English 'here' and 'now': zdes' and tut which can both be glossed as 'here'; sejčas and teper' which can both be glossed as 'now'; and vot which is closer to French voilà, thus combining 'here' and 'now' in a verbal pointing gesture.

The contribution of our investigation can be summarized as follows. First, we demonstrate that the relevant deictic words have partly overlapping meanings; while all the meanings of all the words in question can be described 
by means of one large radial category network, each word has its own "center of gravity" in the network, or, in the terminology we propose, its own radial category profile. Second, we investigate the relationship between time and space and show that while temporal deixis depends on spatial deixis, time is not merely a mirror image of space. Third, we show that language in TV differs from language in other settings - an interesting case in point is the use of sejčas 'now' for the purposes of story segmentation in TV news broadcasts. Fourth, our study has implications for linguistic theory, insofar as radial category profiles and conceptual integration prove to be valuable theoretical tools for the study of deictic words. Finally, with regard to the question we posed in the beginning, we suggest that language adapts to new settings by distributing its resources slightly differently - in fact, the differences are so subtle that thorough linguistic analysis is required in order to shed light on them. In order to capture this insight explicitly, we propose what we call the "Minimal Adaptation Hypothesis".

Our argument is structured as follows. After a brief discussion of the key concept of "blended joint attention" in section 2, we analyze the meanings of the spatial words zdes' and tut in section 3 and the temporal uses of sejčas, teper' and tut in sections 4 and 5 , before we turn to vot in section 6 . The characteristics of language in TV news broadcasts are addressed in section 7, where we introduce the Minimal Adaptation Hypothesis. Conclusions are offered in section 8.

\section{Deixis: Blended Joint Attention}

In order to investigate the use of deictic words in TV, we must pinpoint the differences between the prototypical communication situation and the situation created by TV. We show that these differences can be described adequately in terms of what we call "blended joint attention".

Let us take as our starting point a simple situation where a speaker (encoder) and an addressee (decoder) direct their attention to something present in the immediate space surrounding the two participants, such as a blackbird in a tree. The speaker can point at the bird and say to the addressee: "the blackbird is here now". Although a situation of this type, which we refer to as "classic joint attention" (cf. Tomasello and Farrar 1986), enables us to understand the basis of deixis, deictic words such as here and now and their Russian equivalents are used to refer to many things and abstract entities that are not actually present in the immediate physical surroundings of the speaker and the addressee at the moment of speech. They can jointly attend to their joint memory of something they saw the day before, even though the memory is not something perceptible in their joint environment. Or they can jointly attend to a poem they have memorized, or an imperceptible subject such as an algebraic identity. In cases like these, classic joint attention is extended by means of the cognitive operation of blending.

Blending is a cornerstone in the theory of conceptual integration presented in Fauconnier and Turner (2002) and numerous other publications. The idea is that information from different conceptual arrays ("mental spaces") is combined ("blended") into one mental space ("the blend") where the information is 
compressed so as to be more manageable for the human mind. By way of illustration, consider the following example: ${ }^{1}$

(1) Here is our political correspondent with the details. (http://vrnewsscape.ucla.edu/mind/2012-05-17 Popcorn.html)

The formula "here is $\mathrm{X}$ with $\mathrm{Y}$ " is ubiquitous in news broadcasts, but what exactly does here mean? To begin with, from the audience's point of view, the news anchor's desk is firmly a there. In addition, in the typical television news broadcasts, the anchor's presentation is commonly supplemented with simultaneous live or prerecorded (formerly live) video clips and perhaps one or more news streams at the edge of the screen. For instance, in the following example, the TV screen includes three persons in different locations talking to each other, accompanied by a news stream at the edge of the screen:

(2) Joining me now, Scott Rasmussen, president of rasmussenreports.com and author of The People's Money. Also, Chris Stirewalt, our Fox News digital politics editor and host of Power Play on foxnews.com. Alright, guys, thank you both so much for being here. (http://vrnewsscape.ucla.edu/mind/2012-05-17 Popcorn.html)

For the audience, there just is no shared here. Furthermore, to the extent that collateral material makes reference to different time frames, whether labeled "live" or "prerecorded", the audience's experience of a shared now is compromised.

Seen from the analyst's point of view, the decoder of such a news broadcast is faced with multiple, shifting theres and alternating, possibly indeterminate nows. In the aggregate, such experiences may go beyond the capacity of many viewers. But viewers are not genetically disposed to throw in the towel. Rather, they are disposed to make the most of what there is. The cognitive act that allows viewers to cope with this complex experience, we suggest, is that they create a mental space (a blend) where they counterfactually share a 'here' and 'now' with the people on the TV screen. This blended space incorporates information from a number of mental spaces, including our knowledge about classical joint attention, TV technology, studio environment, reporters in the field and reported events. We refer to this as "blended joint attention". It is important to notice that viewers are not deluded; we know that we do not really share a 'here' and 'now' with the persons on the screen. However, blended joint attention enables the viewers to make sense of the newscasts - including the seemingly confusing use of deictic words. It is an open question how much of this scene of blended joint attention needs to be learned by children. Martha McClintock, a psychologist, reports (personal communication) that when as a child she first saw television with her mother at a neighbor's house, and her mother told her it was time to go

\footnotetext{
${ }^{1}$ Examples from TV network news explored in the present study are excerpted from the NewsScape Library of International Television News, a unit of the University of California Library. It is a searchable but not yet public online database (http://tvnews.library.ucla.edu, authentication required). After each example from TV network news we provide a link to a webpage where the reader can watch the relevant video clips. For the convenience of the reader, throughout the article the relevant deictic words in numbered examples are boldfaced.
} 
home, Martha responded that they could not because it would be rude to leave while "they are talking to us."

Before we leave blended joint attention, it is important to point out that TV is not unique in creating situations that deviate from classic joint attention. A case in point is personal correspondence, when someone reads a personal letter from someone else. Of course, this is not a scene of classic joint attention, but it draws on the joint attention scene to structure the thought and action. Recanti 1995 analyzes grammatical constructions that arise in this scene of blended joint attention, such as a special use of the present tense, which he calls "the epistolary present." The epistolary present is a prompt to blend two quite different moments of action (one person writing, one person reading) to a blended present, as in I have your request before me and you have my answer before you. This is a standard form of time compression. In the blend, writer and reader are both present. Outside the blend, they are not.

An equally familiar scene of blended joint attention is a phone conversation. Imagine two people in different rooms of a high-rise building looking out the windows at something happening in the landscape while they talk on the telephone. Some deictics survive, such as Here's trouble, meaning something like "I see in the scene something that I evaluate as trouble and by saying so I expect that you will be able by inference to locate in the scene what I am referring to, even though I am not otherwise going to direct you to it." But other deictics do not survive. If the second speaker sees two possible candidates for the referent, she cannot intelligibly respond, while pointing, "Do you mean this one or that one?" Nor, if she did, could the first speaker respond, "This one," absent something in the scene (such as a distinctive movement) that would allow the second speaker to infer the referent.

The cognitive operation of blending provides a valuable tool for the analysis of phone conversations, personal letters and TV broadcasts as examples of blended joint attention. In section 7, we will address the use of deictic words in blended joint attention in TV news. However, first we need to explore deictic words in "normal" discourse. This is the topic of sections 3-6.

\section{Space words: zdes' 'here' and tut 'here'}

Although both zdes' and tut can be glossed as 'here', these words are not used interchangeably in all contexts. We argue that even though their meanings can be analyzed in terms of one and the same radial category network, the two words display different radial category profiles, since they have different "centers of gravity" in the network.

In order to investigate the use of zdes', tut and the three other Russian deictic words under scrutiny in the present article, we created five databases, one for each deictic word. Each database contains 150 examples from the modern (post 1950) subcorpus of the Russian National Corpus. ${ }^{2}$ In order to

\footnotetext{
${ }^{2}$ The Russian National Corpus (RNC) is available at www.ruscorpora.ru. Unless otherwise indicated, all numbered examples in sections 3 through 6 of the present study are culled from the RNC. For the convenience of the reader, after each example information about the source is provided in square brackets. For examples from fiction, we give the date and the last name of the author, while for non-fiction examples we give the date and the name of the newspaper or journal.
} 
avoid skewed data, each database is a random sample and contains only one example per document (novel, short story, newspaper article etc.).

There is a long tradition in general and in Slavic linguistics in particular for describing the semantics of grammatical affixes and function words in terms of abstract invariant meanings (cf., e.g., Jakobson 1936). While we do not exclude the relevance of invariant meanings, which can be accommodated as abstract schemas (cf. Langacker 2008), we agree with Wierzbicka (1980), who argues that abstract invariant meanings have limited informative value. We therefore follow common practice in cognitive linguistics, according to which meanings are described in terms of category networks ("radial categories", Lakoff 1987). A radial category may be organized around one or more central subcategories ("prototypes") that are related to the remaining subcategories via extension relations such as metaphor and metonymy.

While more fine-grained analysis is possible, we divide the meanings of zdes' and tut into four subcategories; this is sufficient for the purposes of the present study. First of all, both words are used to locate a place in physical space. Examples from our databases include the following, where zdes' and tut can be paraphrased as $v$ ètom meste 'at this location':

(3) Да и снега бывает здесь меньше, чем в лиственном лесу. [«Наука и жизнь» 2007]

'And there is also less snow here than in a deciduous forest.'

(4) Затем, собственно, он и приходил сюда, чтобы это услышать, и больше у него никаких тут не было дел. [Владимов 1963-1965]

'In the meantime he actually did come here in order to hear it, but he didn't have any other business here.'

However, quite often zdes' and tut refer to the whole situation in a broader sense, including both the physical location and other circumstances. In (5), for instance, we are dealing with a symptom, which is not connected to a physical location, but rather characteristic of a particular situation. In the same way, tut in (6) can be paraphrased as $v$ ètoj situacii 'in this situation', rather than as $v$ ètom meste 'at this location':

(5) Ведущий симптом здесь - нарушение общей и речевой активности. [«Семейный доктор» 2002]

'The main symptom here is disruption of general and speech ability.'

(6) Тут поможет все, что приучает организм к погодным капризам, прежде всего контрастный душ. [«Семейный доктор» 2002]

'Everything that can make the body become accustomed to weather instability, in particular alternating cold and hot showers, will help.'

There are also examples where zdes' and tut refer to a "place" in a text, or in general are used for the purpose of discourse management. Examples (7) and (8) illustrate this:

(7) Она именовалась, быть может, несколько витиевато - «Физикохимическая биология и проблемы медицинской энзимологии», и недельная программа ее постепенно раскручивала круг вопросов от простых белок-липидных взаимодействий молекул до медицинских 
проблем регуляции обмена в норме и при патологии. Впрочем, уместен ли здесь эпитет «простые»? [ «Знание - сила» 1988]

'It was called, perhaps rather ornately "Physio-chemical biology and problems of medical enzymology", and the weekly program gradually developed a series of questions from simple protein-lipid molecular interactions to medical problems of regulating metabolism in normal and pathological situations. However, is the epithet "simple" appropriate here?'

(8) МКА весьма изменчивы, и в 1987 году Эдельман высказал предположение, что система адаптивного иммунитета развилась в эволюции из системы избирательной адгезии. Тут стоит добавить, что избирательная адгезия клеток наблюдается повсюду. [«Наука и жизнь» 2009]

'Monoclonal antibodies are very unstable, and in 1987 Edelman suggested that the adaptive immunity system was developed via evolution from the selective adhesion system. Here it is necessary to add that the selective adhesion of cells is observed universally.'

Although both zdes' and tut are used with spatial meanings, it has been suggested in the literature that "only tut is regularly used as a temporal deictic" (Grenoble 1998: 109). Our data is in accord with this view; we have found temporal examples like (9) with tut, but no corresponding examples with zdes'.

(9) Вот я за столом, отодвигаю ящик и тут замечаю на столе анкету. [Баранская 1969]

'So I am sitting at my desk and I open the drawer and here I notice a questionnaire on the desk.'

The radial category network in Figure 1 relates the four meanings described above. The upper left circle represents the concrete spatial meaning, while the more abstract meanings labeled "situation" and "discourse" are placed to the right. The temporal meaning is placed below the other subcategories, since time represents a domain that is quite different from space, although the two domains are often analyzed as metaphorically related - a fact we return to in the following section, where we will use Mel'čuk's (1985) label "S4" for the relevant temporal meaning. 


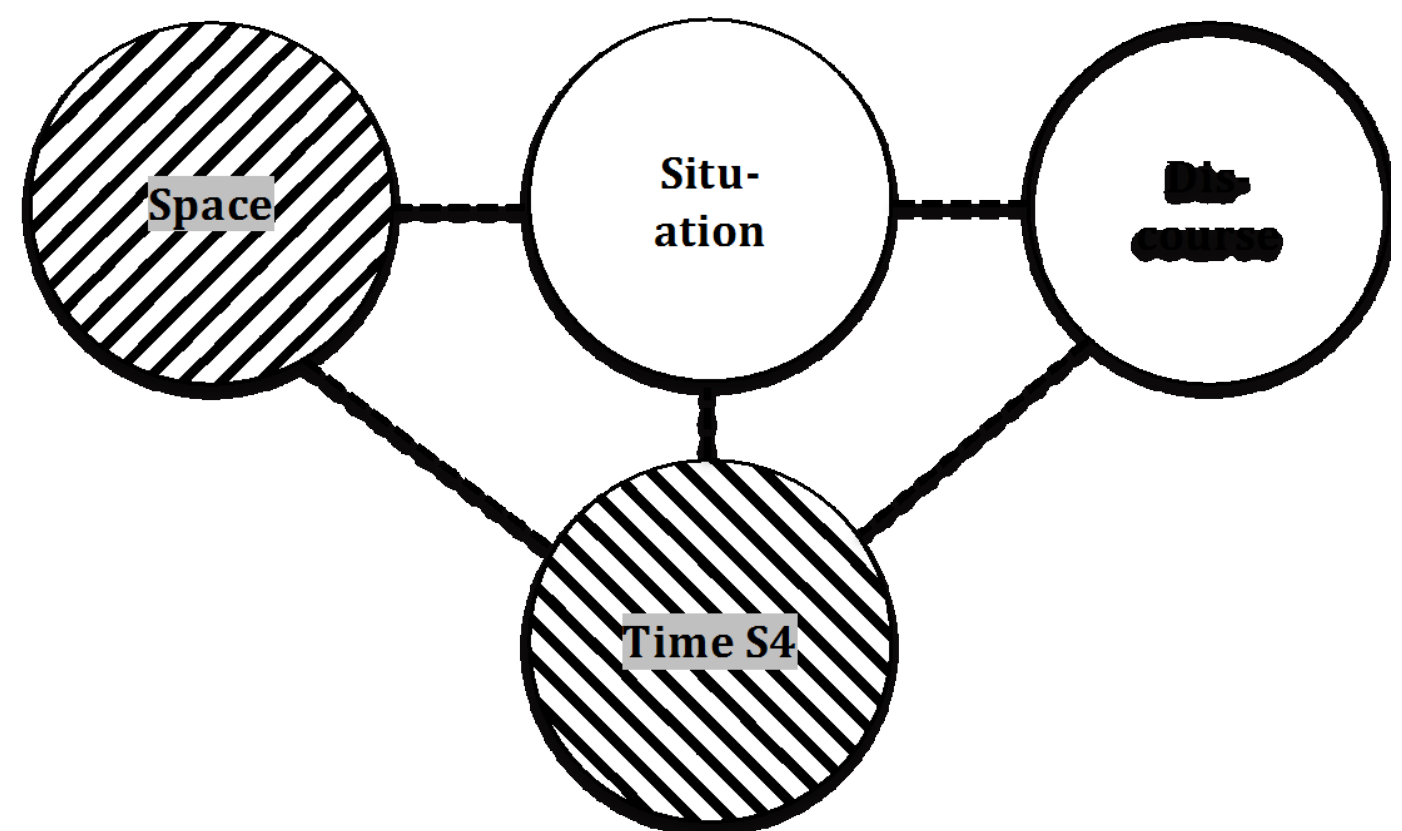

Figure 1: Radial category network for zdes' and tut. Shading patterns represent centers of gravity (ascending diagonal $=z_{d e s}$, descending diagonal $=t u t$ )

Even though zdes' and tut have overlapping distributions, they are not equally frequent in all subcategories. Table 1 summarizes the distributions of the two deictic words across the four subcategories shown in Figure 1. (The table also includes a category "other", which contains a small number of examples that are not easily assigned to any of the four subcategories in Figure 1.) The data are from our random samples of 150 examples from the Russian National Corpus. The table includes both raw numbers (columns marked with the \# sign) and percentages; the percentages are visualized in the bar diagram in Figure 2.

\begin{tabular}{lrrrr} 
& \# zdes' & \# tut & \% zdes' & \% tut \\
\hline Space & 95 & 24 & 63 & 16 \\
Situation & 36 & 48 & 24 & 32 \\
Discourse & 10 & 13 & 7 & 8.5 \\
Time & 0 & 55 & 0 & 37 \\
Other & 9 & 10 & 6 & 6.5 \\
Total & 150 & 150 & 100 & 100
\end{tabular}

Table 1: Radial category profiles for zdes' and tut 


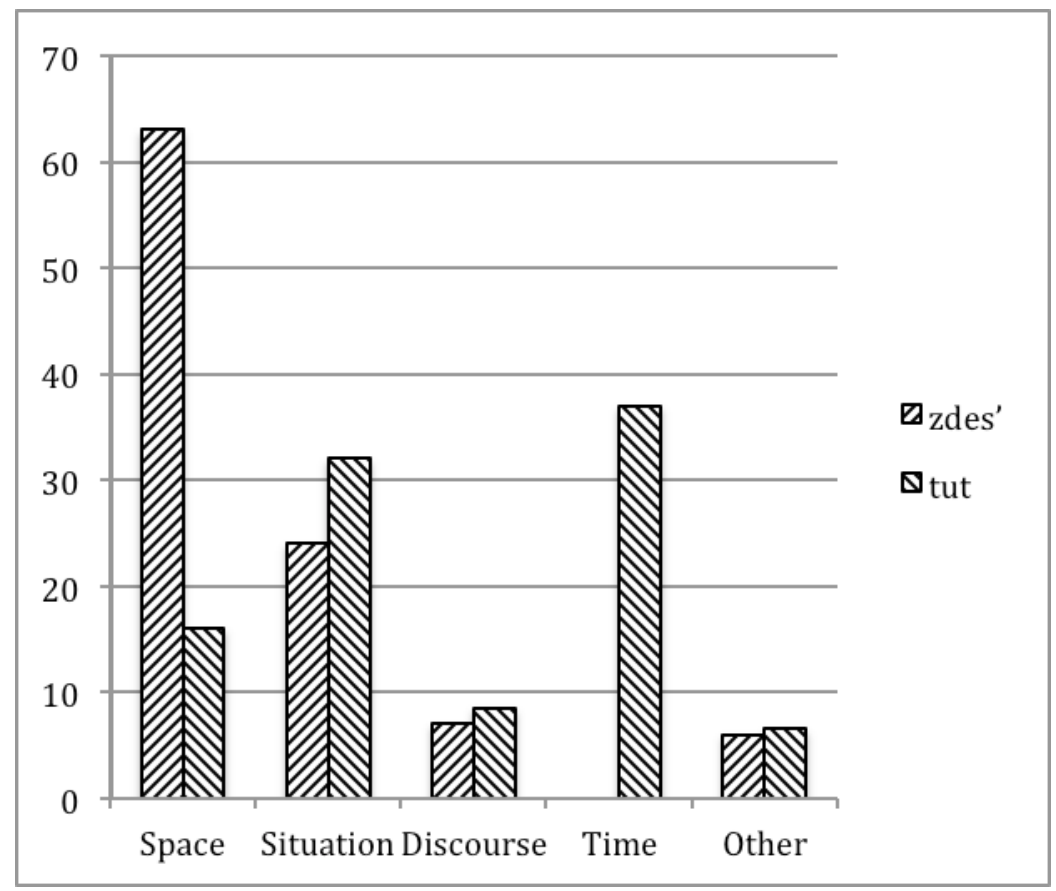

Figure 2: Radial category profiles for zdes' and tut

We refer to a word's frequency distribution across the subcategories of a radial category network as the "radial category profile" of the word (cf. Nesset, Endresen and Janda 2011 and Nesset 2012). Table 1 and Figure 2 show that zdes' and tut have overlapping, but nevertheless different radial category profiles. While for both words the subcategory "situation" is quite frequent $(24 \%$ for $z d e s$ ' and $32 \%$ for tut), zdes' has physical space as its center of gravity, while tut gravitates towards temporal reference. In order to capture the differences between zdes' and tut in Figure 1, we use the same shading patterns as in Figure 2; ascending diagonal lines represent the center of gravity of zdes', while the center of gravity of tut is marked by descending diagonal lines. A simple statistical test shows that the differences observed in Table 1 are statistically significant and that the effect size is large. ${ }^{3}$ Despite the overlap, therefore, there is no doubt that the radial category profiles of zdes' and tut are really different.

We argue that radial category profiling provides a precise account of the meanings and use of zdes' and tut. A simple radial category network shows whether a word is attested or not in a given subcategory. The method of radial category profiling in addition brings out the relative strengths of the relevant subcategories, and thus facilitates a more fine-grained analysis, which is particularly fruitful when we are dealing with words with closely related meanings, such as zdes' and tut. An additional benefit of radial category profiling

\footnotetext{
${ }^{3}$ We performed Pearson's Chi-squared test (X-squared $\left.=99.5196, \mathrm{df}=4\right)$, which gave p-value $<$ $2.2 \mathrm{e}-16$, i.e. the number $0 . . .22$ with fifteen zeros before 22 . The p-value measures the likelihood that the observed differences could be due to chance. Since $2.2 \mathrm{e}-16$ is the smallest number the stastitics software package $\mathrm{R}$ operates with, for all practical purposes the likelihood that the observed differences could be due to chance is zero. Although an observed difference is not likely to be due to chance, this does not necessary mean that the relevant factors have a large impact, i.e., that the effect size is large. In order to investigate the effect size of the factors involved in Table 1, we computed a Cramer's V value. R provided a Cramer's V value $=0.6$, which is considered a large effect size (King and Minium 2008, 327-329).
} 
is the fact that the differences can be quantified and hence subjected to statistical testing.

\section{Time words: sejčas 'now', teper' 'now' and tut 'here/now'}

In the previous section, we saw that tut is used for both spatial and temporal reference. In what follows, we offer a more detailed discussion of temporal deixis, and demonstrate the radial category profile of tut differs from those of sejčas and teper', which can both be glossed as 'now'. Time is often analyzed as a metaphorical extension from space (cf., e.g., Haspelmath 1997). Although we do not dispute the basic insight behind the TIME IS SPACE metaphor, our analysis shows that temporal deixis is not a mere mirror image of spatial deixis.

In his prize-winning book Počemu jazyki takie raznye?, an introduction to linguistics for young adults, V. A. Plungian (2010: 5) uses sejčas and teper' as examples of words that on the face of it seem to be completely synonymous, but nevertheless are not used interchangeably in all contexts. In fact, one sentence may contain both words, as in A teper' ja edu sejčas 'But now I'm leaving immediately' from Tolstoj's War and Peace. ${ }^{4}$ Exploring the subtle semantic differences among temporal deictic words, we take a taxonomy from Mel'čuk (1985) as our starting point. In his analysis of sejčas, Mel'čuk (1985) considers four meanings, which he labels S1-4. The first of these meanings, S1, involves situations that coincide or overlap with the moment of speech (Mel'čuk 1985: 261). We suggest distinguishing between two subtypes, one where we are dealing with an event happening "right now", i.e. coinciding with the moment of speech, and one with a somewhat broader temporal reference, where we are dealing with events that take place "nowadays". Examples of the first subtype are (10), (11) and (12). In all these examples the relevant situations coincide with the moment of speech, and 'now' may be paraphrased as 'right now'. ${ }^{5}$

(10) А сейчас мне нужно дописать вот это. [Шукшин 1958]

'And now I have to finish writing this thing.'

(11) Если часть [...] капель током воздуха заносится выше, то некоторые из них могут замерзнуть и стать зародышами градин. Теперь ясно, что размер градин будет зависеть от концентрации замерзающих капелек. [«Химия и жизнь» 1969]

'If some of the droplets are carried upward by a stream of air, then some of them can freeze and become cores for hailstones. Now it is clear that the size of hailstones will depend on the density of freezing droplets.'

(12) Положа руку на сердце, тут же приходится перемещать ее вместе со второй за голову: признать что-то из показанного в Экспериментальной шедевром, а кого-либо из авторов гением затруднительно. [«Театральная жизнь» 2003]

\footnotetext{
4 The authors would like to thank Stephen M. Dickey for drawing our attention to this example.

${ }^{5}$ It is worth pointing out that tut is very often followed by the particle že, which, as argued by Rakhilina and Letuchiy (2012), emphasizes that the event in question takes place right after another event, i.e., is part of a chain of consecutive events.
} 
'When you want to be honest, then you have to think carefully: it is difficult to accept one of the works as an Experimental masterpiece and one of the artists as a genius.'

Examples (13)-(14), on the other hand, involve reference to a broader time span overlapping with the moment of speech. In these examples, 'now' means 'nowadays'. This subtype is not attested for tut in our database.

(13) - Смелее надо мыслить! Сейчас все создают рок-группы. Вот и мы свою создадим. [LiveJournal 2004]

'We need to think more boldly! Everyone is setting up rock groups these days. Let's set up one ourselves.'

(14) Теперь в любой точке земного шара можно работать над этими факсимиле, ранее доступными только в архивах Пушкинского Дома. [«Известия» 2001]

'Now it is possible to work on these facsimiles anyplace in the world. Previously they were available only in the archives of the Puškinskij dom.'

The second subtype recognized in Mel'čuk's (1985: 264) taxonomy, S2, involves reference to a point in time following the moment of speech. In (15)(17), for example, the deictic words may be paraphrased as 'in a moment': 6

(15) Я вам сейчас расскажу о том, что же случилось с нами. [Радов 2003] 'Now I am going to tell you about what happened to us.'

(16) Филипп посмотрел на них и сказал: - Идите на двор! - Теперь поговорим о государственных делах, - вздохнул король. [Ладинский 1960]

'Philippe looked at them and said: Go outside! Now let's talk about state issues, sighed the king.'

(17) Сев на водительское место, вставьте ключ в замок зажигания и тут же его вытащите. [«Автопилот» 2002]

'After sitting in the driver's seat, place the key in the ignition and then remove it again immediately.'

Mel'čuk (1985: 267) provides examples where sejčas refers to a time just before the moment of speech, S3. We did not find any examples of this type in our databases, but examples like (18) with sejčas are attested in the Russian National Corpus. However, we have not been able to find parallel examples with teper' or tut.

\footnotetext{
${ }^{6}$ Note in passing that word order is of relevance in sentences like (15)-(17). In (15), for instance, sejčas could be replaced by teper', but only if teper' was placed in sentence-initial position (teper' ja vam rasskažu). Sentences (15)-(17) involve perfective verbs, but imperfective verbs are also attested in examples of this type:

(i) Сейчас будем чай пить. [Панова 1959] 'Now we are going to drink tea.'

(ii) Дальнейшие результаты теперь будут определяться итогами работы комиссии. [«Воздушно-космическая оборона» 2004]

'Future results will now be determined based on the conclusions of the committee's work.'
} 
(18) Надо спросить у того, с кем я сейчас разговаривала... [Улицкая 2000] 'We should ask the person I was just talking to...'

Constructions with a perfective verb in the past tense plus sejčas and teper' represent an interesting borderline case between S1 (reference to the moment of speech) and S3 (reference to a moment before the moment of speech). On the one hand, such verbs describe an event in the past, but at the same time they involve a resultant state that overlaps with the moment of speech. In (19), for instance, uspokoilsja 'calmed down' describes both a change of state in the past and a resultant state (to be calm) in the present.

(19) Сейчас уже успокоился. Но сначала думал, что сойдет с ума от радости. [Коллекция анекдотов 1970-2000]

'Now he has calmed down. But at first he thought that he would go mad with joy.'

In the same way, in (20) složilas' 'was formed' at the same time denotes a change of state in the past and a resultant state in the present.

(20) Если требованиям первого варианта законопроекта соответствовала добрая половина компаний, то теперь сложилась прямо противоположная ситуация. [«ПОЛИТКОМ.РУ» 2003]

'If a good half of the companies were in compliance with the requirements of the first version of the law, now the situation has changed.'

We assign sentences like (19) and (20) to the S1 subtype, since sejčas and teper' refer to the resultant state, rather than the event that created this state (cf Mel'čuk 1985 and Padučeva 1996: 271 for discussion). In (19), for instance, sejčas in sejčas on uspokoilsja 'he has calmed down now' may be paraphrased as sejčas on spokoen 'he is calm now', where sejčas refers to a state described by an adjective, which encodes no information about any preceding events in the past tense.

Mel'čuk (1985: 267) characterizes the temporal reference in his fourth subcategory, S4, as follows: "v dannyj moment, imevšij mesto $\mathrm{v}$ prošlom, no predstavljaemyj govorjaščim kak moment reči”. By way of example, consider (21):

(21) Все, что говорил сейчас Зураб, Сергею казалось естественным. [Искандер 1977]

'Everything that Zurab was saying now, seemed natural to Sergej.'

The past tense form govoril 'said' indicates that we are dealing with an event in the past. At the same time, the use of sejčas 'now' describes this event as if it were unfolding at the moment of speech. We analyze this as a "deictic shift" whereby in the mind of the speaker and the addressee the deictic center ("here and now") is moved back in time. The effect is a more vivid presentation of events in the past, since through the deictic shift they are more closely connected to the present. Deictic shifts of this type are attested for teper' and tut as well, as shown in (22) and (23): 
(22) Там стояли большие навесы, где когда-то сушили кирпич. Теперь они были пустыми. [Шульгин 1971]

'There stood some large sheds, where bricks were previously being dried. Now they were empty.'

(23) Сообщалось, что теперь на территории России запретят пользоваться латинским алфавитом (тут невольно вспоминался некий майор Шестаков, объявивший [...], что Солженицыну официально запрещено писать). [«Отечественные записки» 2003]

'It was reported that the use of the Latin alphabet would be prohibited on Russian territory (at this point we are reminded of mayor Šestakov, who announced that Solzhenitsyn was officially forbidden to write).'

In a sense, the deictic shift construction in (21)-(23) is the mirror image of to the so-called historical present (praesens historicum). Whereas in (21)-(23) a verb in the past tense co-occurs with a deictic word referring to the present, in the historical present a verb in the present tense combines with deictic elements such as togda 'then', which indicate that the event took place in the past. Another construction involving a conflict between the verbal tense and the meaning of a deictic element is the zavtra + past tense construction investigated by Chernova (2010):

(24) Завтра они уезжали из Тегерана. [Тынянов 1928]

'The following day they were leaving Teheran.'

However, rather than involving a deictic shift, examples like (24) prompt a reinterpretation of the deictic word; zavtra receives the meaning 'the day after (an event in the past)' instead of its normal meaning 'tomorrow'.

Parallels for the deictic shift construction exist in other languages. Nikiforidou (2010, in press) investigates English examples like the silence of a cold windless night was all he heard now, where the deictic word 'now' combines with a past tense verb. Nikiforidou (in press) presciently comments that the past + now pattern has "an effect of zooming in on the events." Interestingly, when occurring in TV news broadcasts the past + now construction is often supported by a zooming in by the camera, as in the following clip from the Communication Studies Archive (CSA) at the University of California:

(25) I now saw that Johnson was continuing the pattern of presidential lying. (http://vrnewsscape.ucla.edu/mind/2012-05-17 Popcorn.html)

In Figure 3 we propose a radial category network for the temporal meanings of sejčas, teper' and tut. Comparing the networks in Figures 1 and 3, we are in a position to comment on the TIME IS SPACE metaphor mentioned in the beginning of this section. The basic insight in the metaphorical approach to time and space is that in thinking and speaking about the abstract domain of time we draw on our knowledge about the more concrete domain of space. Our analysis of deixis supports this. The spatial deictic word tut is quite frequently used in temporal deixis, suggesting a close relationship between the domains of time and space. Additionally, the concept of locating events as prior to, simultaneous with and posterior to the moment of speech plays an important role in our analysis of temporal deictic words. Since "location" is clearly a spatial notion, this way of 
conceptualizing time is spatial, and hence metaphorical in nature. At the same time, our analysis does not indicate that temporal deixis is a mere mirror image of spatial deixis in our conceptualization, insofar as the temporal network in Figure 3 is quite different from the (primarily) spatial network in Figure 1. In this way, our analysis resonates with the ideas of space-time asymmetries in Nesset (2011) and Makarova and Nesset (this volume, see also Kuznetsova, Plungian and Rakhilina this volume and Plungian and Rakhilina this volume).

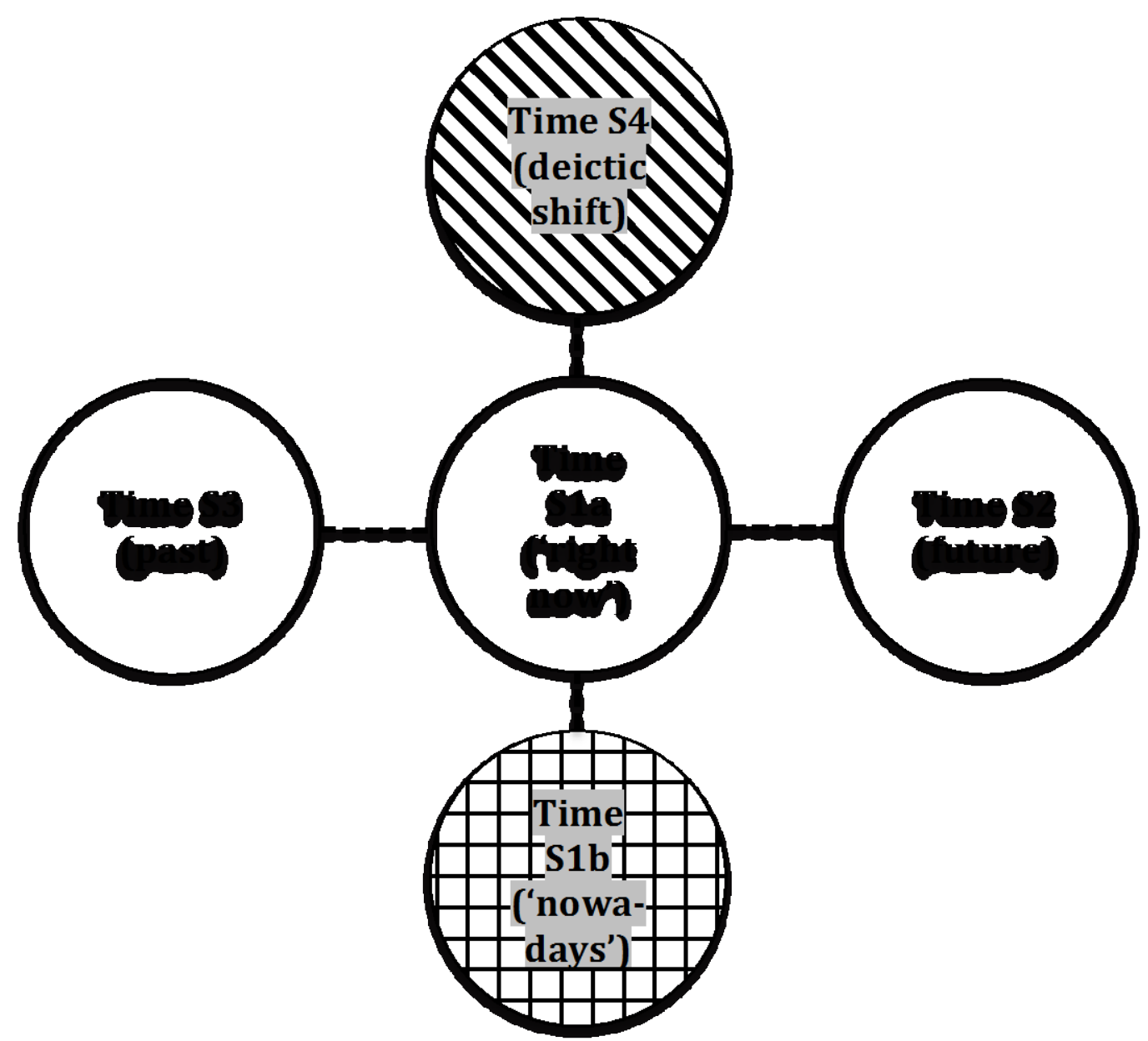

Figure 3: Radial category network for sejčas, teper' and tut. Shading patterns represent centers of gravity (descending diagonal $=t u t$, horizontal $=$ sejčas, vertical $=$ teper')

Table 2 and Figure 4 show the frequency distribution of the three deictic words across the five submeanings in the radial category network. Two conclusions can be drawn from Table 2 and Figure 4. First, the radial category profile of tut is quite different from that of sejčas and teper'; while tut gravitates towards the deictic shift construction (S4), sejčas and teper' most frequently occur in the S1b "nowadays" subcategory. Second, the radial category profiles of sejčas and teper' are quite similar. ${ }^{7}$ The question therefore arises as to whether it

\footnotetext{
7 These conclusions are corroborated by statistical test. Comparison of the numbers for sejčas and teper' on the one hand and tut on the other reveals that the observed differences are statistically highly significant: Pearson's Chi-squared test (X-squared $=167.4934, \mathrm{df}=2)$ gave $\mathrm{p}$ value $<2.2 \mathrm{e}-16$. The effect size is large: Cramer's V-value $=0.7$. Comparison of the numbers for sejčas and teper', on the other hand, shows that the differences between these two deictic words are not statistically significant: Pearson's Chi-squared test $(\mathrm{X}$-squared $=3.0945, \mathrm{df}=3) \mathrm{p}$-value $=$
} 
is possible to tease apart the differences between sejčas and teper'. We address this question in the following section.

\begin{tabular}{lrrrrrr} 
& \#sejčas & \#teper' & \#tut & \%sejčas & \%teper & \%tut \\
\hline S1a 'now' & 13 & 11 & 2 & 9 & 7.3 & 4 \\
S1b 'nowadays' & 109 & 102 & 0 & 73 & 68 & 0 \\
S2 (future) & 17 & 17 & 4 & 11 & 11.3 & 7 \\
S3 (past) & 0 & 0 & 0 & 0 & 0 & 0 \\
S4 (deictic shift) & 11 & 20 & 49 & 7 & 13.3 & 89 \\
Total & 150 & 150 & 55 & 100 & 100 & 100
\end{tabular}

Table 2: Radial category profiles for temporal deixis with sejčas, teper' and tut

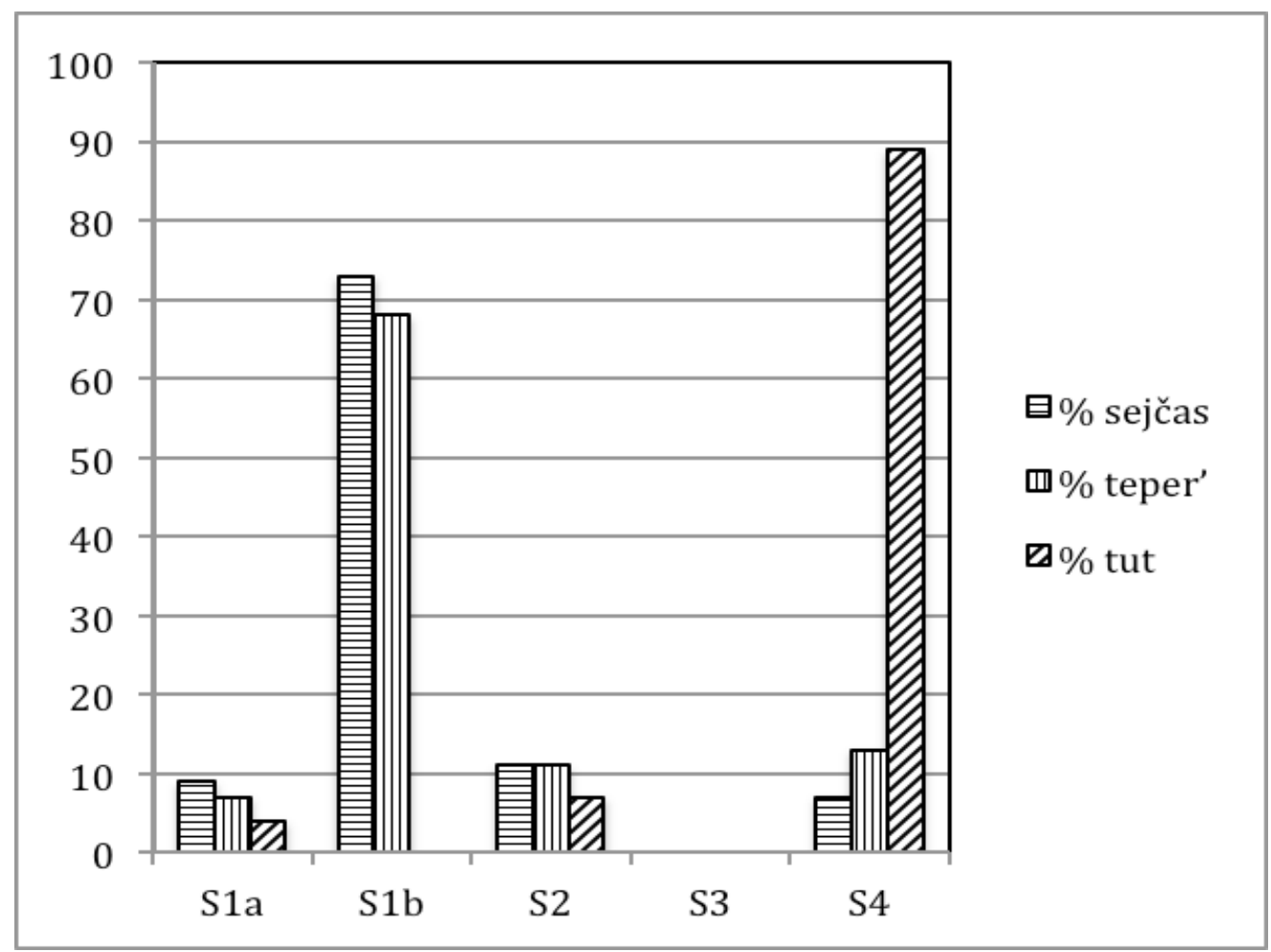

Figure 4: Radial category profiles for temporal deixis with for sejčas, teper' and tut

\section{More on time words: contrast vs. no contrast}

It has often been suggested in the literature that teper' and sejčas are different in that the meaning of teper', but not sejčas involves a contrast (cf., e.g., Grenoble 1998: 102, Mel'čuk 1985: 270). In this section, we present empirical evidence from the Russian National Corpus in favor of this analysis. However, we show that the relevant contrast is not always primarily temporal, but may also involve modality and specificity.

Let us first look at a typical example where teper' is used to describe a contrast between what is going on 'now' and what took place ran'še 'earlier':

0.3773. Notice that for the purposes of statistical analysis we did not distinguish between subcategories S1a and S1b, and that we did not include S3 in the analysis, since this subcategory is not attested in our databases. 
(26) Раньше на станции горел прожектор, светились окна. Теперь все погрузилось во мрак. [Песков 1983-1984]

'Previously there was a searchlight blazing at the station and the windows were lit. Now everything is plunged in darkness.'

While contrasts between two temporal planes are typical for sentences with teper', our databases also contain examples with sejčas in contexts involving temporal contrast:

(27) Сейчас многие из нас молчат, и никто не обращает на это внимания. A в прежние времена нас берегли, любили и уважали. [«Трамвай» 1990]

'Now many of us are silent and no one pays any attention to that. But in previous times we were taken care of, loved, and respected.'

However, more frequently sejčas occurs in contexts where no such contrast is present. In (13), which is here repeated as (28), for instance, the fact that "everybody forms rock groups nowadays" is not explicitly compared to earlier times:

(28) - Смелее надо мыслить! Сейчас все создают рок-группы. Вот и мы свою создадим. [LiveJournal 2004]

'We need to think more boldly! Everyone is setting up rock groups these days. Let's set up one ourselves.'

We have three attestations of teper' in non-contrastive contexts; (29) is illustrative:

(29) Мы часто теперь слышим, что в недавнем прошлом кто-то кому-то не помогал. [«Жизнь национальностей» 2002]

'We often hear now that not so long ago someone failed to help someone else.'

Returning to examples involving a contrast, we mentioned above that such contrasts are not necessarily purely temporal, although temporal contrasts are most frequent in our databases. Consider (30), where teper' is used in a conditional construction in the subjunctive mood:

(30) Если бы ошибки не случилось, он получил бы 15 очков, однако теперь эти очки приписываются сопернику. [«Наука и жизнь» 2007]

'If no mistake had been made, he would have gotten 15 points, however now those points go to his opponent.'

The contrast in (30) is modal rather than temporal, insofar as we are dealing with a comparison between a hypothetical situation, where no mistakes were made, and the real situation, which involves a number of mistakes. Sentence (31) shows that sejčas is also attested in similar contexts, although this sentence is not in the subjunctive. 
(31) Если сейчас не вытащить Москву из финансового болота, скоро в нем могут оказаться и другие европейские страны. [«Вечерняя Москва» 1998]

Example (31) illustrates that there is no clear-cut boundary between temporal and modal contrasts since in (31) a contrast between what is going on now and a future situation is also present.

Example (32) emphasizes a contrast between a general state of affairs and the specific situation occurring 'now':

(32) Литература, искусство, воспоминания молодости, светские сплетни вот был круг их всегдашних разговоров. Теперь они толковали о шляпках. [Улицкая 1993]

'Literature, art, memories of youth and celebrity gossip - these were the contents of their constant conversations. Now they were discussing hats.'

The context provides a list of topics of conversation that includes svetskie spletni 'celebrity gossip'. Teper' introduces a sentence that describes the current topic of conversation, namely hats, which can be considered a specific instance of the general term svetskie spletni. We are here dealing with an arguably temporal opposition between 'usually' (i.e., habitual) and 'now' (i.e., actual) and a contrast between a general term and a specific instance.

Table 3 describes the relative distribution of contrastive and noncontrastive uses of teper' and sejčas. Our data lend strong support to the idea that teper' involves a temporal or other contrast. Sejčas, on the other hand, gravitates towards non-contrastive use. We conclude that the two temporal deictic words have quite different radial category profiles.

\begin{tabular}{lrrrr} 
& \#Contrast & \#No contrast & \%Contrast & \%No contrast \\
\hline sejčas & 30 & 120 & 20 & 80 \\
teper $^{\prime}$ & 147 & 3 & 98 & 2
\end{tabular}

Table 3: Contrastive vs. non-contrastive uses of sejčas and teper'

\section{Vot: pointing and joint attention}

The deictic element vot has received considerable attention in the scholarly literature (cf. e.g. Grønn 1999, Nikolaeva 1985 and Grišina 2008 and references therein). In the following video clip, where vot occurs 17 times in 17 seconds, vot is used to draw attention to the damage caused by water leaking through the ceiling of an apartment.

(33) Вот. Вот, смотрите, вот стены, вот они все, вот до каких пор. Вот, вот они вот полы все поднятые. Вот это смотрите, вот все. Вот это спаси в общем не знаю скоро и это гореть не будет. Только сегодня утром вот. Вот она уже капает! Вот она уже мокрая стала, вот она, вот! Уже вот. (http://vrnewsscape.ucla.edu/mind/2012-05-17 Popcorn.html)

'Look. Here, you see, look at the walls, here they all are, look how much. Look, look, all these floors are buckled up. Here look at this, all this here. Look at this, heavens, in general I don't know and it won't be working. This 
happened just this morning. See it is dripping already! See it has gotten wet already, look at it, look! See already.'

Although vot fulfills a variety of functions in this discourse, it seems fair to say that it prototypically serves as the verbal equivalent of the pointing gesture. ${ }^{8}$ In the following, we will adopt a simple classification. While our classification does not do vot full justice, it is sufficient to shed light on similarities and differences between vot and other deictic elements - which is the main objective of the present study.

As the linguistic equivalent of the pointing gesture, vot arguably incorporates spatial and temporal deixis in one lexical item; by "pointing" at the damaged parts of the apartment in (33) vot indicates that this damage is relevant both 'here' and 'now'. Sentence (34) is a corpus example where vot is used to draw attention to a concrete, physical object in the deictic situation, in this case a fur hat:

(34) Вот шапка-ушанка из оленьего меха от колхозницы. [Каменская 1989] 'Here is a fur hat made from deer presented by the kolkhoz worker.'

Vot is also used to point at a location in space, typically co-occurring with tut as in (35). However, the second occurrence of vot in (35) shows that tut is not obligatory in such contexts:

(35) Вот тут у березы я себе поставлю дом. И вот с этого боку крылечко. [Кнорре 1962]

'Here by the birch tree I will build myself a house. And here on this side a porch.'

Sentence (36) illustrates the temporal use of vot; in this sentence vot has approximately the same function as the temporal conjunction kogda 'when':

(36) Вот оно уйдет, кто о нем будет говорить? [«Совершенно секретно» 2003]

'Now it will disappear, and who is going to talk about it?'

In its temporal use, vot sometimes co-occurs with temporal adverbials, such as snova 'again' in (37):

(37) И вот снова такая же, если еще не более жесткая ситуация. [«Восточно-Сибирская правда» 1998]

'And here again is a similar, if not even more extreme situation.'

An important function of vot is discourse management; metaphorically speaking, vot "points" at a part of discourse. In (38), for instance, vot introduces direct speech:

(38) Вот мнение управляющего партнера компании «ФБК»: «Возможным последствием [...] станет интеграция компаний». [«Известия» 2001]

\footnotetext{
${ }^{8}$ The relationship between deictic words and gesture has recently been studied in great detail by Talmy (2011).
} 
'Here is the opinion of the director of the company "FBK": A possible outcome is a merger of the companies.'

In (39), on the other hand, vot draws attention to the completion of direct speech.

(39) Ты дура необразованная, вот что я тебе скажу. [Хаецкая 1997]

'You are an uneducated fool, that's what I have to say to you.'

Vot can also be used to signal that one is returning to a topic previously discussed:

(40) Так вот, в большом времени ничто и никогда не утрачивает своего значения. [Бахтин 1971]

'So in the long run nothing ever loses its significance.'

In (41), vot (in combination with ili 'or') draws attention to the change of topic, whereas in (42) vot points at an example:

(41) И так сразу за пять курсов. Или вот. Сидят приятели, выпивают. [«Столица» 1997]

'And do it this way for all five years. And here's another one. Some friends are sitting and drinking.'

(42) -Расскажите, какой был микроклимат в команде. - На мой взгляд, замечательный! Хотя, конечно, надо расспросить ребят! Вот Саша Моисеенко, например, говорил, будто я объявлял состав прокурорским тоном, не терпящим возражений. [«64 - Шахматное обозрение» 2004]

'-Tell me what the atmosphere was like in the team. -In my opinion, it was great! But you'd better ask the guys! Saša Moiseenko here, for example, said that I was announcing the lineup like a prosecutor with no tolerance for objections.'

The radial category profile of vot is summarized in Table 4. We distinguish between five subcategories. In addition to "deictic situation", which encompasses examples like (34), and space, time and discourse, we include a category "other", since vot is a versatile lexical item with a multitude of functions. The limitations of this classification notwithstanding, the table and the figure suffice to demonstrate that vot gravitates toward discourse management, which accounts for nearly half the examples in our database.

\begin{tabular}{lll} 
& \# examples & \% examples \\
\hline Deictic situation (e.g. example 34) & 25 & 16.5 \\
Space (e.g. example 35) & 4 & 3 \\
Time (e.g. example 36) & 24 & 16 \\
Discourse (e.g. example 38) & 72 & 48 \\
Other & 25 & 16.5 \\
Total & 150 & 100
\end{tabular}

Table 4: Radial category profile for vot 


\section{Adapting to a new setting: discourse management in "ordinary language" and TV news}

With the analysis of zdes', tut, sejčas, teper' and vot in the Russian National Corpus in place, we return to the question stated in the beginning of this article, namely what happens to language when it adapts to a new setting. Our data suggest that the use of deictic words in TV news is different from other settings; in particular we show that sejčas is the preferred means of carrying out story segmentation under blended joint attention. We conclude that blended joint attention does not impose radical changes on language. In order to adapt to this new setting, language only needs to redistribute its existing resources very slightly. In order to capture this insight, we advance what we call the "Minimal Adaptation Hypothesis".

In order to investigate deictic words in TV news broadcasts, we uploaded 5.81 hours of Russian TV network news broadcasts to the NewsScape Library of International Television News at UCLA. The material was transcribed, and then annotated and analyzed manually by means of the tools available at the NewsScape Library of International Television News. We excerpted all instances where a news anchor or a reporter in the field uttered the relevant deictic words while addressing the viewers directly (i.e. looking into the camera). ${ }^{9}$ The resulting database consists of 102 attestations of deictic words. Table 5 and Figure 5 summarize the distribution of the five deictic words in our TV news database. In addition, the table and figure include the frequencies of the deictic words in the modern subcorpus of the Russian National Corpus (RNC), i.e., the part that covers the period after 1950. Since TV news involves oral discourse (although news anchors sometimes read prepared texts), we also included numbers from the oral subcorpus of RNC. Although the RNC data represent numbers of a different magnitude, which makes comparison difficult, there are some striking differences that call for comment.

First, the table shows that the four deictic words zdes', tut, sejčas and teper' account for between $16 \%$ and $18 \%$ of the corpus data, whereas vot is much more frequent. Second, the distribution in the TV news database is very different. Compared to the modern subcorpus of the RNC, sejčas and to some extent vot are overrepresented in TV news, while tut and teper' are strongly underrepresented. Third, if we compare the numbers from TV news with the oral subcorpus of the RNC, we see that tut and teper' are infrequent in both corpora, and that vot has high frequencies in both corpora. It stands to reason, therefore, that the fact that tut and teper' are underrepresented in TV news and vot is overrepresented is due to the oral genre. However, the distribution of sejčas in TV news cannot be explained as an oral effect. As can be seen from Table 5, sejčas represents $17 \%$ of the examples in the modern subcorpus of the RNC and 19\% in the oral subcorpus, while the corresponding number in TV news is 33\%. Even though we are dealing with a small database for TV news, our data suggest that the use of sejčas is different in TV news broadcasts.

\footnotetext{
${ }^{9}$ We limited ourselves to situations where anchors or reporters addressed the viewers directly, since these are the situations relevant for blended joint attention.
} 


\begin{tabular}{lrrrrrr} 
\#RNC & $\begin{array}{r}\text { \#RNC } \\
\text { (oral) }\end{array}$ & \#TV & $\begin{array}{r}\text { \%RNC } \\
\text { (post 1950) }\end{array}$ & $\begin{array}{r}\text { \%RNC } \\
\text { (oral) }\end{array}$ & \%TV \\
\hline zdes' & 91,950 & 18,487 & 21 & 16 & 11 & 21 \\
tut & 100,105 & 12,648 & 1 & 17 & 7 & 1 \\
sejčas & 98,598 & 32,458 & 34 & 17 & 19 & 33 \\
teper' & 102,556 & 9,478 & 2 & 18 & 5 & 2 \\
vot & 189,612 & 102,345 & 44 & 33 & 58 & 43 \\
total & 582,821 & 175,416 & 102 & 100 & 100 & 100
\end{tabular}

Table 5: Distribution of deictic words in the Russian National Corpus (RNC) and TV news

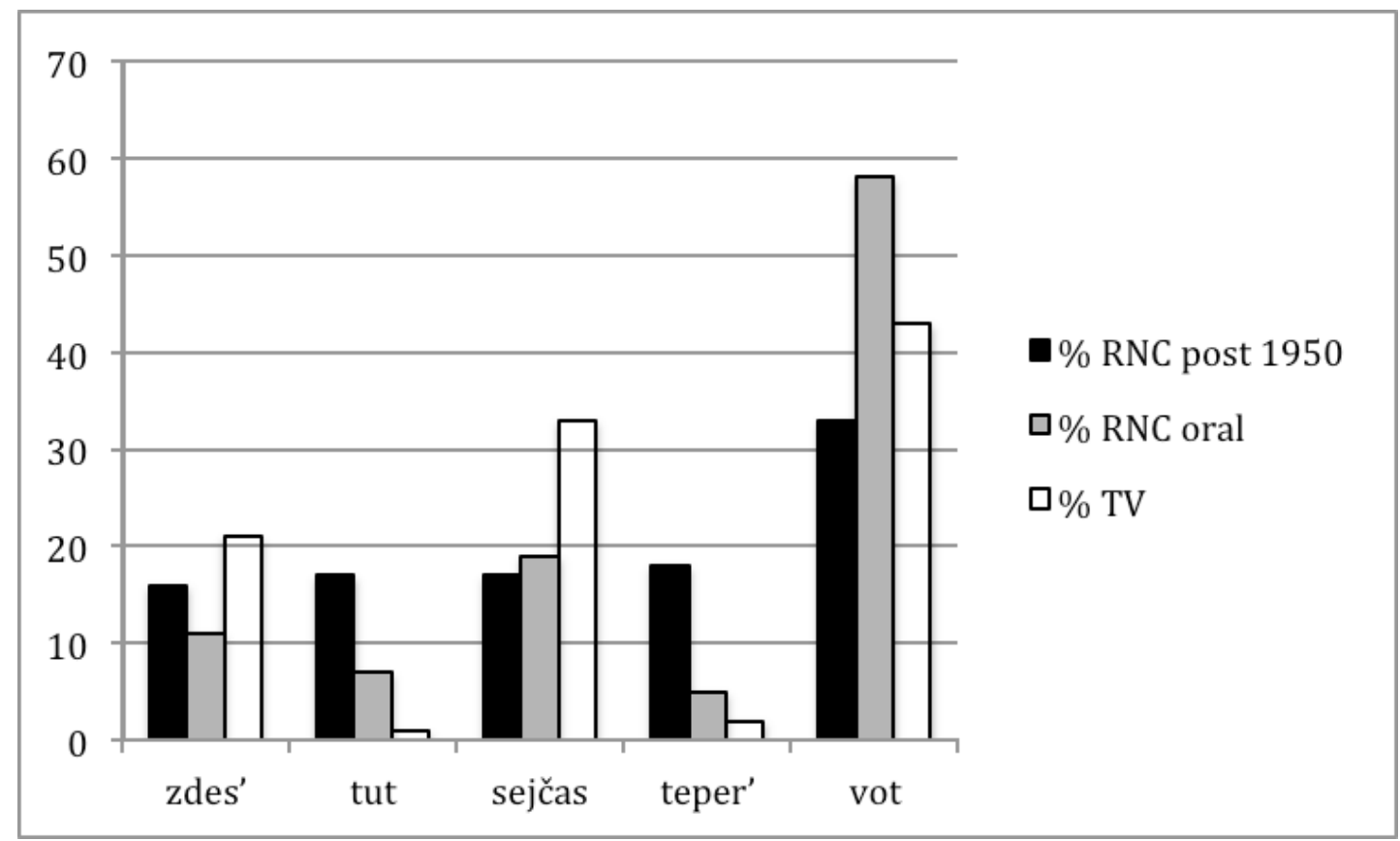

Figure 5: Distribution of deictic words in the Russian National Corpus (RNC) and TV news

In order to find out, we examined examples involving "story segmentation", i.e., situations where a news anchor (or sometimes a reporter in the field) introduces an upcoming story. Story segmentation is interesting because it involves blended joint attention - the news anchor informs the viewers what comes next in the blend. Our data material from Russian news broadcasts includes fourteen clear examples. Ten of the examples contain sejčas, while vot is used in the remaining four examples. Here are two characteristic examples:

(43) На прямой связи из Южной Осетии сейчас корреспондент пятого канала Евгений Лукинов.

'Live from South Ossetia, here is Evgenij Lukinov, Channel 5 correspondent.'

(44) Вот репортаж Алексея Лазуренко из наземной и подземной частей Большого театра. (http://vrnewsscape.ucla.edu/mind/2012-05-

17 Popcorn.html)

'Here is a report from Aleksej Lazurenko from the Bolshoy theater both above and below ground.'

Although our data material is limited, it seems that the conventional way to perform story segmentation in Russian TV news broadcasts involves sejčas. The second option, vot, appears to be more stylistically marked and more 
characteristic of improvised, rather than carefully prepared speech. A case in point is (45), which was uttered by a reporter in the field introducing the story of the eyewitnesses to the suicide bomb attack in the Domodedovo airport in January 2011. Clearly, the reporter has not had time to prepare what he is going to say, and it is natural that he uses vot, which as shown in Table 5 is very frequent in oral genres.

(45) И у нас есть фрагменты рассказов тех очевидцев, которые во время находились в зале прилета международных рейсов, и вот что они рассказывают. (http://vrnewsscape.ucla.edu/mind/2012-0517 Popcorn.html)

'We also have excerpts of reports from the eyewitnesses who were in the international arrivals hall at the time and here is what they say.'

The question now arises as to why Russian prefers a temporal deictic word (sejčas) for the purposes of story segmentation. We argue that the Minimal Adaptation Hypothesis offers an explanation:

(46) The Minimal Adaptation Hypothesis:

When applied to a new setting, language makes adaptations that are as small as possible.

In order to clarify the implications of this hypothesis for story segmentation, we need to go back to blended joint attention. In the situation of story segmentation, spatial deixis is compromised. What is here for the people on the screen is in reality there for the viewers. In other words, it is only in the blend that news anchors, reporters in the field and TV viewers share a here. The temporal deictic center, on the other hand, is not compromised. In examples such as (43)-(45), in actual reality the viewers do share a now with the people introducing a story on the screen, since we are dealing with live transmission. In view of the fact that temporal deixis involves less of a conflict between the deictic perspective of the viewers and the people on the screen, the Minimal Adaptation Hypothesis predicts temporal deixis to be preferable in story segmentation in TV news. The fact that Russian TV conventionally uses sejčas for this purpose, suggests that the Minimal Adaptation Hypothesis is on the right track.

At this point two questions arise. First of all, we must ask how the use of vot in examples like (44) and (45) squares with the Minimal Adaptation Hypothesis. We argue that such examples are not at variance with the hypothesis, since vot is not an example of purely spatial deixis. As we pointed out in section 6, vot is the verbal equivalent of the pointing gesture and is used to draw attention to something that is relevant both here and now. Since the meaning of vot is equally relevant for time and space, we argue that the occasional use of this word for the purposes of story segmentation in TV news is not at variance with the Minimal Adaptation Hypothesis.

A second question regards English. As mentioned in section 2, the construction "here's $\mathrm{X}$ with the latest news from $\mathrm{Y}$ " is ubiquitous in story segmentation in news broadcasts in English. Isn't the use of the spatial deictic word here a counterexample to the Minimal Adaptation Hypothesis? We cannot exclude the possibility that there are differences between language communities, and that speakers of English may be willing to put up with more conflicting uses 
of spatial deictic words than speakers of Russian are. At the same time, we would like to point out that here is not a clear-cut example of spatial deixis in English, but rather shares many features with Russian vot. By way of example, consider the Russian phrase vot vam kniga, which is used when the speaker hands over a book (or some other object) to the addressee. In this situation, a native speaker of English may use phrases like here's a book for you or (if the book has already been introduced in the relevant discourse) here you are or here you go (without mentioning the book). Such phrases, we argue, do not primarily focus on the location of the book (here vs. there), but rather on the fact that the book has now been passed over to the addressee. In other words, in many uses of here in English, temporal deixis is at least as important as spatial concerns. In view of this, we suggest that English here does not provide substantial counterevidence to the Minimal Adaptation Hypothesis.

Although we have presented the Minimal Adaptation Hypothesis as a hypothesis about language in TV network news, we note that it may be considered a hypothesis about language change in general. As such it predicts that language change takes place in small steps, rather than abrupt and dramatic changes. While detailed discussion of the general mechanisms of language change is well beyond the scope of the present study, we would like to point out that there is considerable support for the idea of small-step language change in the literature. A case in point is grammaticalization, which is often argued to proceed in small steps along a grammaticalization cline (cf., e.g., Hopper and Traugott 2003, 6 et passim; Heine et al. 1991, 223 et passim).

\section{Conclusions: five questions and answers}

Our analysis of zdes', tut, sejčas, teper' and vot affords five conclusions. The first question we have addressed is: what do deictic words mean? We have argued that they have different centers of gravity in radial category networks. In other words, they have different radial category profiles. The two networks we have presented in sections 3 and 4 can be combined, as in Figure 6, which has also been extended so as to distinguish between the contrastive and non-contrastive uses of teper' and sejčas discussed in section 5. Although, as shown in the figure, the five deictic words under scrutiny gravitate toward different subcategories in the network, it is important to notice that the meanings of the deictic words to a large extent overlap; radial category profiles reflect statistical tendencies, not absolute boundaries between abstract invariant meanings. 


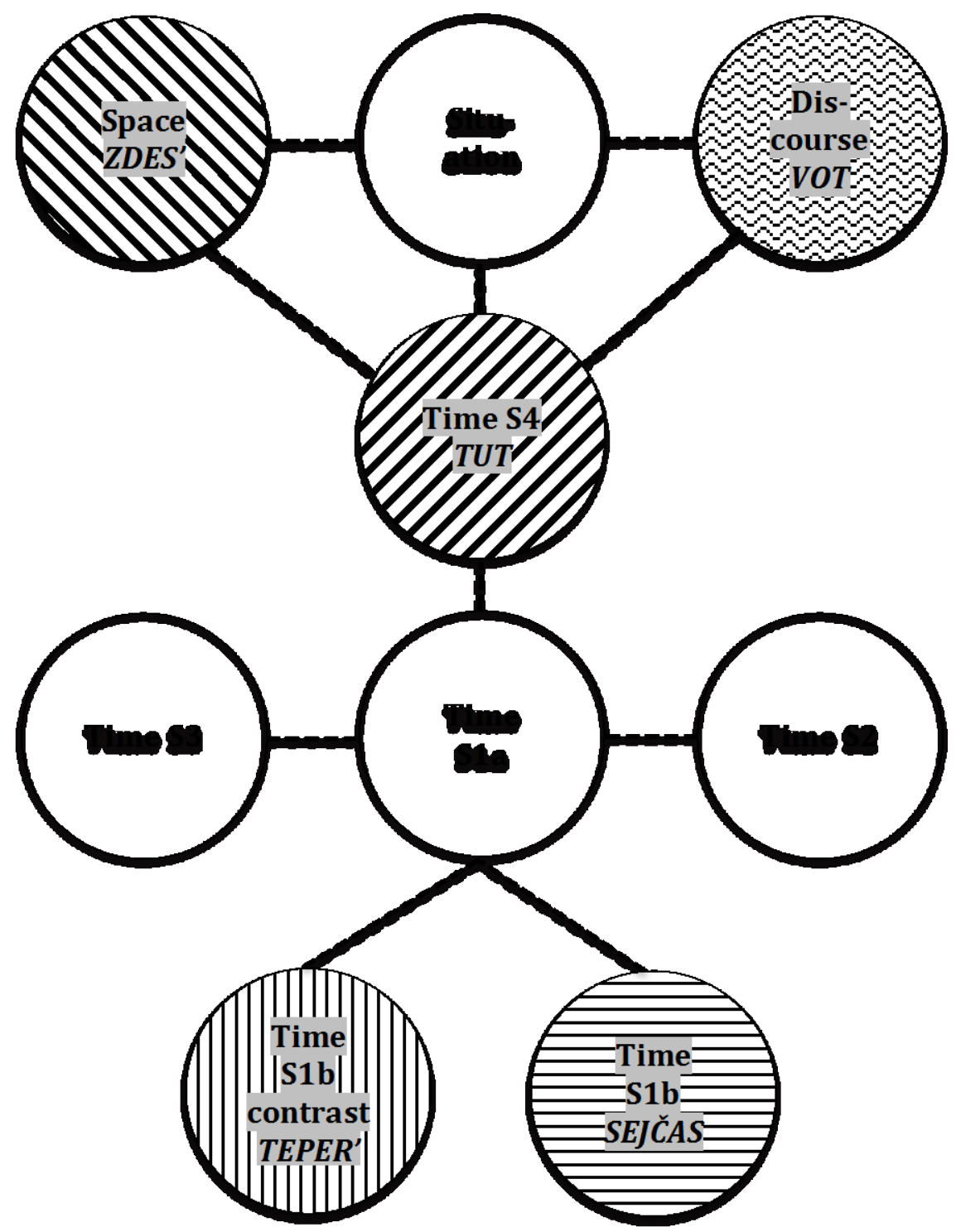

Figure 6: Combined radial category network for spatial and temporal deixis. Shading patterns (adopted from previous figures) represent centers of gravity.

The second question we have discussed is what the deictic words we have analyzed tell us about the relationship between time and space in language. In section 4 we pointed out that temporal deixis depends on spatial deixis. The use of tut in temporal contexts can be considered a metaphorical extension from space, and the concept of location in time, which is important in the analysis of sejčas and teper', is also metaphorical in nature. At the same time we have seen that the temporal part of the network in Figure 6 is not a mere mirror image of the spatial part of the network, thus suggesting that the domains of time and space have some autonomy. Another part of our analysis that testifies to the autonomy of time vis-à-vis space concerns vot. As argued in section 6, as the verbal equivalent of the pointing gesture vot incorporates both spatial and temporal deixis without giving primacy to either domain. In conclusion, our analysis supports the view that temporal language depends on spatial language, as suggested in the TIME IS SPACE metaphor, but at the same time we see that time has considerable autonomy vis-à-vis space. 
Third, one may ask: what are the implications for linguistic theory of the analysis we have proposed? Three theoretical concepts have played a role in our analysis: the radial category, radial category profiling and blending (conceptual integration). The radial category enables us to describe the meanings of deictic words as networks of interrelated subcategories. Radial category profiling allows us to capture the frequency distributions of the subcategories in the radial category networks. Blending and, more generally, Conceptual integration theory (Fauconnier and Turner 2002) facilitates the analysis of the communication situation in TV news broadcasts in terms of blended joint attention. Since the radial category, radial category profiling and blending have proved to be valuable tools for the understanding of deictic words, our analysis lends support to linguistic theories that are compatible with these theoretical concepts.

A fourth question is whether language in TV news broadcasts is different from language in other settings. Even though the empirical material from TV we have analyzed in the present study is quite limited, our analysis suggests that there are non-trivial differences. While all five deictic words are attested in TV news, they seem to have a somewhat different frequency distribution compared to data from the Russian National Corpus. Furthermore, the observed differences appear to be connected to blended joint attention.

The fifth and perhaps most important question we have addressed in this study can be stated as follows: how does language adapt to a new setting? In response to this question we have advanced the Minimal Adaptation Hypothesis, according to which language makes adaptations as small as possible when applied to new settings such as the complex communication situation in TV news. The fact that Russian prefers temporal rather than spatial deixis in story segmentation provides some evidence in favor of this hypothesis, in the sense that Russian prefers temporal deixis in story segmentation, which minimizes the conflict between deixis under classical and blended joint attention. The Minimal Adaptation Hypothesis has far-reaching implications for our understanding of language under blended joint attention, and more generally for language in TV. Hopefully, the future will bring large searchable corpora of Russian TV news broadcasts, facilitating more thorough empirical testing of the Minimal Adaptation Hypothesis than was possible in the present study.

\section{References}

Chernova, D.: 2010, Figurative use of the past tense in Russian: a case study, Poljarnyj Vestnik 13, 33-47.

Fauconnier, G. and M. Turner: 2002, The way we think, New York.

Grenoble, L. A.: 1998, Deixis and information packaging in Russian discourse, Amsterdam/Philadelphia.

Grišina, E. A.: 2008, Častica vot: variant, ispol'zuemye v neprinuždennoj reči, Slavica Helsingensia 34, 63-91.

Grønn, A.: 1999, Subjektiv-modale partikler i russisk. En semantisk og pragmatisk analyse av partikkelen vot. Meddelelser fra slavisk-baltisk avdeling 81, Oslo.

Haspelmath, M.: 1997, From Space to Time: Temporal Adverbials in the World's Languages, Munich.

Heine, B., U. Claudi and F. Hünnemeyer: 1991, Grammaticalization: A Conceptual Framework, Chicago. 
Hopper, P. J. and E. C. Traugott: 2003, Grammaticalization (second edition), Cambridge.

Jakobson, R.: 1936, Beiträge zur Allgemeinem Kasuslehre: Gesamtbedeutungen der russischen Kasus, Travaux du Cercle lingvistique de Prague 6, 240-288.

King, B.M. and E. Minium: 2008, Statistical Reasoning in the Behavioral Sciences, Hoboken, NJ.

Kuznetsova, J., V. Plungian and E. Rakhilina: this volume, Time as a side-effect of space: Russian pod 'under' and iz-pod 'from-under' in temporal constructions, Russian Linguistics.

Lakoff, G.: 1987, Women, Fire, and Dangerous Things, Chicago.

Langacker, R. W. (2008). Cognitive Grammar: A Basic Introduction, New York.

Makarova, A. and T. Nesset: this volume, Time/Space asymmetries: the case of $v$ 'in(to)', Russian Linguistics.

Mel'čuk, I. A.: 1985, Semantičeskie ètudy. I. 'Sejčas' i 'teper' v russkom jazyke, Russian Linguistics 9. 2/3, 257-279.

Nesset, T.: 2011. Space-Time Asymmetries in Russian Prepositions: Preliminary Analysis, Poljarnyj Vestnik 14, 45-62.

Nesset, T.: 2012. One or several categories? The Old Church Slavonic no-verbs and linguistic profiling, accepted for publication in Russian Linguistics.

Nesset, T., A. Endresen and L. A. Janda: 2011, Two ways to get out: Radial Category Profiling and the Russian prefixes vy- and iz-, Zeitschrift für Slawistik 56.4, 377-402.

Nikiforidou, K.: 2010, Viewpoint and construction grammar: The case of past + now, Language and Literature 19(2), 265-284.

Nikiforidou, K.: in press for 2012, The constructional underpinnings of viewpoint blends: The Past + now in language and literature. In: B. Dancygier \& E. Sweetser (eds.): Viewpoint and Perspective in Language and Gesture, Cambridge.

Nikolaeva, T.M.: 1985, Dejktičeskie časticy i izolirovannaja situacija. Dejksis situacii v celom, Russian Linguistics 9. 2/3, 281-288

Padučeva, E.V.: 1996, Semantičeskie issledovanija, Moscow.

Plungian, V. A.: 2010, Počemu jazyki takie raznye?, Moscow.

Plungian, V. and E. Rakhilina: this volume, Time and speed: where do speed adjectives come from? Russian Linguistics.

Rakhilina, E. V. and Alexander Letuchiy: 2012, Time and place in adverbial space, paper presented at the conference Time and Space in St. Petersburg, March 29-30, 2012.

Recanati, F.: 1995, Le présent épistolaire: une perspective cognitive, L'Information grammaticale 66, 38-44.

Talmy, L.: 2011, Target cuing. Talks presented at the The 9th China International Forum on Cognitive Linguistics, Beijing, July 3-9, 2011.

Tomasello, M. and M. J. Farrar: 1986, Joint Attention and Early Language, Child Development 57.6: 1454-1463.

Wierzbicka, A.: 1980, The case for surface case, Ann Arbor. 